\title{
Steroids from the Brazilian Zoanthids Palythoa caribaeorum and Palythoa variabilis
}

\author{
Francisco C. L. Pinto, ${ }^{a}$ José Gustavo L. Almeida, ${ }^{a}$ Edilberto R. Silveira, ${ }^{a}$ Arinice M. \\ Costa, ${ }^{b}$ Larissa A. Guimarães, ${ }^{b}$ Diego V. Wilke, ${ }^{b}$ Leticia V. Costa-Lotufo, ${ }^{c}$ Maria da \\ Conceição M. Torres ${ }^{d}$ and Otília Deusdênia L. Pessoa*,a
}

\author{
${ }^{a}$ Departamento de Química Orgânica e Inorgânica, Universidade Federal do Ceará, \\ 60021-970 Fortaleza-CE, Brazil \\ ${ }^{b}$ Departamento de Fisiologia e Farmacologia, Universidade Federal do Ceará, \\ 60430-270 Fortaleza-CE, Brazil \\ 'Departamento de Farmacologia, Universidade de São Paulo, \\ 05508-900 São Paulo-SP, Brazil \\ ${ }^{d}$ Departamento de Química, Universidade Estadual da Paraíba, \\ 58429-500 Campina Grande-PB, Brazil
}

\begin{abstract}
Two unreported ergostane-type sterols $24(R)$-7 $\alpha$-hydroperoxy-ergost-5-en-3 $\beta$-ol and

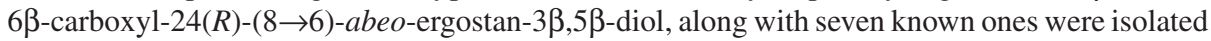
from the hexane and alcohol extracts from the zoanthids Palythoa caribaeorum and Palythoa variabilis. The structures of the new compounds were determined using spectroscopic techniques, including 1D and 2D nuclear magnetic resonance (NMR), high-resolution electrospray ionization mass spectrometry (HRESIMS), and comparison with data previously published. $6 \beta$-Carboxyl$24(R)$ - $(8 \rightarrow 6)$-abeo-ergostan-3 $\beta, 5 \beta$-diol showed moderate cytotoxicity against colon cancer cells (HCT-116) as previously described for others $a b e o$-sterol derivatives.
\end{abstract}

Keywords: Palythoa caribaeorum, Palythoa variabilis, ergostane sterols, cytotoxic activity

\section{Introduction}

Zoanthids are cnidarians found in most marine environments, from temperate to tropical areas and from the intertidal zone to the deep sea below $5000 \mathrm{~m}$, but are particularly common in tropical and subtropical seas. ${ }^{1}$ The colonial zoanthid genus Palythoa (order Zoantharia) is represented by ca. 92 species. $^{2}$ It has been the subject of constant taxonomy investigations due to an incomplete understanding of their diversity. ${ }^{3}$ Many chemical and pharmacological studies have been conducted in order to investigate its biological potentialities. Several classes of compounds have been isolated from zoanthids, including ceramides, ${ }^{4}$ fatty acids,${ }^{5}$ mycosporins, ${ }^{6}$ palytoxins,${ }^{7}$ peptides, ${ }^{8}$ sterols, ${ }^{9}, 10$ zoanthoxanthins, ${ }^{11}$ prostaglandins, ${ }^{12}$ lipidic $\alpha$-amino acids, ${ }^{13}$ and pyrazines. ${ }^{14}$ Lipids and steroids represent the commonest classes of compounds isolated from Palythoa spp. (Figure 1). The most potent toxic non-

*e-mail: otilialoiola@gmail.com protein known, palytoxin, has been isolated from Palythoa species. ${ }^{15}$ The first natural lipid $\alpha$-amino acids $\left(\mathrm{C}_{30}\right.$ and $\mathrm{C}_{31}$ ) have been isolated from Protopalythoa variabilis, and exhibited cytotoxic effects against human cancer cell lines. ${ }^{13}$ Protopalythoa taxonomy previously assigned ${ }^{4,13}$ is under revision based on mitochondrial DNA analysis, indicating that Protopalythoa and Palythoa are indeed congeneric designations. ${ }^{16}$

The present investigation reports on the steroidal composition of $P$. caribaeorum and $P$. variabilis. Both species are abundant in shallow waters along the Brazilian Northeast coastline.

\section{Experimental}

\section{General}

Infrared (IR) spectra were obtained on a PerkinElmer FT-IR spectrum 1000 spectrometer. Optical rotations were measured on a PerkinElmer 341 digital polarimeter at $25^{\circ} \mathrm{C}$. 


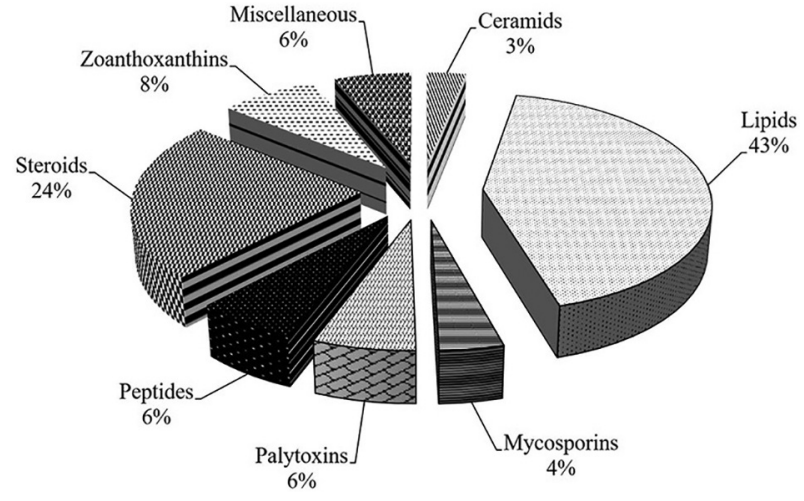

Figure 1. Percentage distribution by classes of the isolated, or identified, compounds from Palythoa species.

Melting points, not corrected, were determined on a digital MQAPF-302 melting point apparatus (Microquimica), with a heating rate of $2{ }^{\circ} \mathrm{C} \mathrm{min}^{-1} .{ }^{1} \mathrm{H}(500$ or $300 \mathrm{MHz})$ and ${ }^{13} \mathrm{C}(125$ or $75 \mathrm{MHz})$ nuclear magnetic resonance (NMR) spectra were performed either on a Bruker Avance DRX-500 or Avance DPX-300 spectrometer. High resolution electrospray ionization mass spectrometry (HRESIMS) was acquired using a liquid chromatography-mass spectrometry ion trap and time-of-flight (LCMS-IT-TOF, Shimadzu) spectrometer, consisting of an UFLC (ultra fast liquid chromatography) system coupled to an IT-TOF mass spectrometer equipped with electrospray ionization (ESI) source operating either in positive or negative mode. The mass spectra were recorded in the range of $m / z 100-1000 \mathrm{Da}$, using a potential of $4.0 \mathrm{kV}$ on the capillary, and nitrogen as the desolvation gas. The system was controlled by a LC-solution software, which was also used for data analysis. High-performance liquid chromatography (HPLC) analysis was carried out using an UFLC (Shimadzu) system equipped with a SPD-M20A diode array UV-Vis detector and a Phenomenex $\mathrm{C}_{18}$ column, $5 \mu \mathrm{m}(4.6 \times 250 \mathrm{~mm})$. The mobile phase consisted of $\mathrm{H}_{2} \mathrm{O}-\mathrm{CH}_{3} \mathrm{CN}$ with a flow rate of $4.72 \mathrm{~mL}$ $\mathrm{min}^{-1}$. For the column chromatography $(\mathrm{CC})$ procedures, silica gel 60 [70-230 mesh (Vetec) or 230-400 mesh (Merck)], or Strata $\mathrm{C}_{18}$-E cartridge $(20 \mathrm{~g} / 60 \mathrm{~mL}, 55 \mu \mathrm{m}, 70 \AA$, Phenomenex) were used. Thin layer chromatography (TLC) was performed on pre-coated $0.2 \mathrm{~mm}$ silica gel aluminum sheets (silica gel $60 \mathrm{~F}_{254}$, Merck), and the spots visualized by heating (ca. $100{ }^{\circ} \mathrm{C}$ ) the plates sprayed with a vanillin/ perchloric acid/EtOH solution.

\section{Marine organisms}

Both zoanthids, Palythoa caribaeorum and Palythoa variabilis, were collected during low tide at Paracuru beach $\left(3^{\circ} 24^{\prime} 0.22^{\prime \prime} \mathrm{S}\right.$ and $\left.39^{\circ} 0^{\prime} 48.60^{\prime \prime} \mathrm{W}\right)$, on the west coast of Ceará State, Brazil. Initially, the material was washed with sea water and then stored under refrigeration. Specimens, P. caribaeorum (voucher No. 000976) and P. variabilis (voucher No. 000975), were authenticated by Dr Antonio Carlos Marques and deposited at the Museu de Zoologia, Universidade de São Paulo (MUZUSP-USP).

\section{Extraction and isolation}

The chemical investigation of $P$. caribaeorum and $P$. variabilis was conducted in two different ways. The first one was performed using the usual method, i.e., extraction with $\mathrm{EtOH}$ at room temperature and gravitational column chromatography over silica gel, while the second one was performed using extraction by sonication with $\mathrm{MeOH}$, liquid-liquid partition, SPE (solid phase extraction) cartridges and HPLC chromatography.

P. caribaeorum ( $4.7 \mathrm{~kg}$ ) and $P$. variabilis $(3.4 \mathrm{~kg})$, were cut in small pieces, washed with distilled water, dried at room temperature and extracted with $n$-hexane and then followed by EtOH 96\% (3 times $6 \mathrm{~L}$ for each solvent), for $24 \mathrm{~h}$. The $n$-hexane and EtOH extracts were filtered and evaporated under reduced pressure at $40{ }^{\circ} \mathrm{C}$ to yield, respectively, the crude extracts: 21.0 and $61.7 \mathrm{~g}$ from P. caribaeorum, and 19.8 and $23.3 \mathrm{~g}$ from P. variabilis.

The $P$. caribaeorum $n$-hexane extract $(21.0 \mathrm{~g})$ was initially fractionated over silica gel CC (108 g) using as the elution solvent $n$-hexane, $n$-hexane/EtOAc 4:1, 3:2, 2:3, 1:4, EtOAc and, finally, MeOH. The $n$-hexane/EtOAc 3:2 fraction $(0.9 \mathrm{~g})$ was subjected to silica gel CC by elution with $n$-hexane/EtOAc gradient $(7: 3 \rightarrow 0: 10)$ and then with $\mathrm{MeOH}$ to give 6 fractions (F1-F6), after TLC analysis. F6 $(107.5 \mathrm{mg})$, a white amorphous powder, was washed with EtOAc to afford the pure compound $\mathbf{1}(31.5 \mathrm{mg})$.

The $P$. variabilis $n$-hexane extract $(19.8 \mathrm{~g})$ was fractionated over a silica gel $\mathrm{CC}$ by elution with $n$-hexane, n-hexane/ $\mathrm{CH}_{2} \mathrm{Cl}_{2}$ 1:1, $\mathrm{CH}_{2} \mathrm{Cl}_{2}, \mathrm{CH}_{2} \mathrm{Cl}_{2} /$ EtOAc 1:1, EtOAc, and, finally, $\mathrm{MeOH}$. The $\mathrm{CH}_{2} \mathrm{Cl}_{2} / \mathrm{EtOAc} 1: 1$ fraction $(4.3 \mathrm{~g}$ ) was subjected to silica gel $\mathrm{CC}$ using a gradient of $n$-hexane/ EtOAc (7:3 $\rightarrow$ 0:10) followed by $\mathrm{MeOH}$ to yield 6 subfractions (F1-F6), after TLC analysis. F4 (197.2 mg) was subjected to silica gel CC by elution with an isocratic solvent system consisting of $n$-hexane/EtOAc 7:3 to afford compound $2(28.3 \mathrm{mg})$.

Additional samples of $P$. caribaeorum $(2.0 \mathrm{~kg})$ and $P$. variabilis $(1.8 \mathrm{~kg})$ were extracted with $\mathrm{MeOH}$ $(3 \times 1000 \mathrm{~mL})$ under sonication for 15 minutes. The $\mathrm{MeOH}$ suspensions were filtered and concentrated under reduced pressure to approximately $1 / 3$ of the total volume and then partitioned with $n$-hexane, $\mathrm{CH}_{2} \mathrm{Cl}_{2}$ and EtOAc $(3 \times 200 \mathrm{~mL}$ of each solvent), from which were obtained the corresponding materials: $3.0,0.9$ and $0.5 \mathrm{~g}$ from 
P. caribaeorum and 11.2, 0.1 and $0.2 \mathrm{~g}$ from P. variabilis, after solvent evaporation under reduced pressure.

The EtOAc fraction (0.5 g), obtained from P. caribaeorum, was fractionated through a $\mathrm{C}_{18} \mathrm{SPE}$ cartridge using a gradient of $\mathrm{MeOH} / \mathrm{H}_{2} \mathrm{O}(2: 8 \rightarrow 10: 0)$ as eluent. The $\mathrm{H}_{2} \mathrm{O} / \mathrm{MeOH} 6: 4(22.0 \mathrm{mg})$ and $\mathrm{H}_{2} \mathrm{O} / \mathrm{MeOH}$ 4:6 (14.0 mg) fractions were further purified by HPLC using a semi-preparative $\mathrm{C}_{18}$ column, a solvent gradient of $\mathrm{H}_{2} \mathrm{O}\left(0.1 \%\right.$ TFA)/ $\mathrm{CH}_{3} \mathrm{CN}(9.5: 0.5 \rightarrow 1: 9.0)$, at a flow rate of $4.7 \mathrm{~mL} \mathrm{~min}^{-1}$, affording peaks with retention times $\left(\mathrm{t}_{R}\right)$ corresponding to 20-hydroxyecdysone ${ }^{17}(4.6 \mathrm{mg}$, $\mathrm{t}_{R}=13.0 \mathrm{~min}$ ), 3- $O$-acetyl-20-hydroxyecdysone ${ }^{17}(2.6 \mathrm{mg}$, $\left.\mathrm{t}_{R}=14.9 \mathrm{~min}\right)$ and 2-O-acetyl-20-hydroxyecdysone ${ }^{17}$ $\left(1.4 \mathrm{mg}, \mathrm{t}_{R}=15.6 \mathrm{~min}\right)$.

The EtOAc fraction $\left(1.0 \mathrm{mg} \mathrm{mL}^{-1}\right)$ from $P$. variabilis was subjected to HPLC using the conditions above mentioned. Following this procedure, and by comparison with the retention time, UV and MS the sterols 20-hydroxyecdysone, 3-O-acetyl-20-hydroxyecdysone and 2-O-acetyl-20-hydroxyecdysone were identified (Figure S19, Supplementary Information (SI)).

\section{4(R)-7 $\alpha$-Hydroperoxy-ergost-5-en-3 $\beta$-ol (1)}

White amorphous powder; m.p. $127.1{ }^{\circ} \mathrm{C} ;[\alpha]_{\mathrm{D}}^{20}-34.0^{\circ}$ (c 0.04, $\mathrm{CHCl}_{3}$ ); IR (KBr) $v_{\max } 3425,3297,2936,2875$, 1461, 1376, 1058; ${ }^{1} \mathrm{H}$ and ${ }^{13} \mathrm{C}$ NMR data, see Table 1; positive HRESIMS $\left(\mathrm{m} / \mathrm{z} 433.3597[\mathrm{M}+\mathrm{H}]^{+}\right.$, calcd. for $\mathrm{C}_{28} \mathrm{H}_{49} \mathrm{O}_{3}, 433.3676$ ).

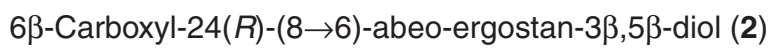

White amorphous powder; m.p. $182.5^{\circ} \mathrm{C} ;[\alpha]_{\mathrm{D}}^{20}+28.0^{\circ}$ (c 0.06, $\mathrm{CHCl}_{3}$ ); IR (KBr) $v_{\text {max }} 3492,2948,2928,1711$, 1152, 1081; ${ }^{1} \mathrm{H}$ and ${ }^{13} \mathrm{C}$ NMR data, see Table 1; negative HRESIMS $\left(m / z, 447.3428[\mathrm{M}-\mathrm{H}]^{-}\right.$, calcd. for $\mathrm{C}_{28} \mathrm{H}_{47} \mathrm{O}_{4}$, 447.3474).

\section{Cytotoxic activity}

The cytotoxic potential of $\mathbf{2}$ was assessed against a human colorectal tumor cell line (HCT-116), obtained from the Banco de Células do Rio de Janeiro (RJ, Brazil), using the 3-(4,5-dimethyl-2-thiazolyl)-2,5diphenyl-2 $H$-tetrazolium (MTT) reduction assay as described previously by Mosmann. ${ }^{18}$ Cells were seeded at $5 \times 10^{4}$ cells $\mathrm{mL}^{-1}$, treated with vehicle ( $\left.0.4 \% \mathrm{DMSO}\right)$, or with 2 at concentrations ranging from 0.007 to $110 \mu \mathrm{M}$ and incubated for 24 or $72 \mathrm{~h}$ under $5 \% \mathrm{CO}_{2}$ atmosphere at $37{ }^{\circ} \mathrm{C}$. Doxorubicin was used as positive control to confirm the proper sensitivity of the cell line. The inhibition concentration mean $\left(\mathrm{IC}_{50}\right)$ values were calculated along with their respective $95 \%$ confidence intervals, of at least two experiments, by nonlinear regression using the software GraphPad Prism 6.0.

\section{Cellular counting and viability}

Cell viability was estimated on the basis of membrane integrity and evaluated by staining with propidium iodide (PI). HCT-116 cells were seeded in a 24 -well plate $\left(5 \times 10^{4}\right.$ cells $\left.\mathrm{mL}^{-1}\right)$ and treated with 2 at 20,40 or $80 \mu \mathrm{M}$ for $24 \mathrm{~h}$ along with vehicle $(0.4 \% \mathrm{DMSO})$ or $3.5 \mu \mathrm{M}$ doxorubicin, as negative and positive controls, respectively. Cells were harvested with trypsin-EDTA 0.1\% (Gibco, New York, USA), centrifuged and resuspended in a $5 \mu \mathrm{g} \mathrm{mL}{ }^{-1}$ PI solution (Sigma-Aldrich, Saint Louis, USA). After 5 min incubation in the dark, ten thousand events were acquired using the Accuri C6 flow cytometer (BD Biosciences, Franklin Lakes, NJ, USA), on a gated region to exclude debris and doublets from the analysis. The experiments were repeated six times. The differences between negative control and experimental groups were determined by analysis of variance (ANOVA) followed by Dunnett's test using GraphPad Software 6.0 (Intuitive Software for Science, La Jolla, CA, USA). The minimal significance level was set at $p<0.05$.

\section{Results and Discussion}

The chemical investigation of the extracts from the Brazilian zoanthids $P$. caribaeorum and $P$. variabilis allowed the isolation and characterization of two new steroids $\mathbf{1}$ and $\mathbf{2}$ (Figure 2), in addition to seven known sterols (Figure S1).

Compound 1, an amorphous white powder, m.p. $127.1^{\circ} \mathrm{C}$; $[\alpha]_{\mathrm{D}}^{20}-34.0^{\circ}\left(c 0.04, \mathrm{CHCl}_{3}\right)$ had its molecular formula
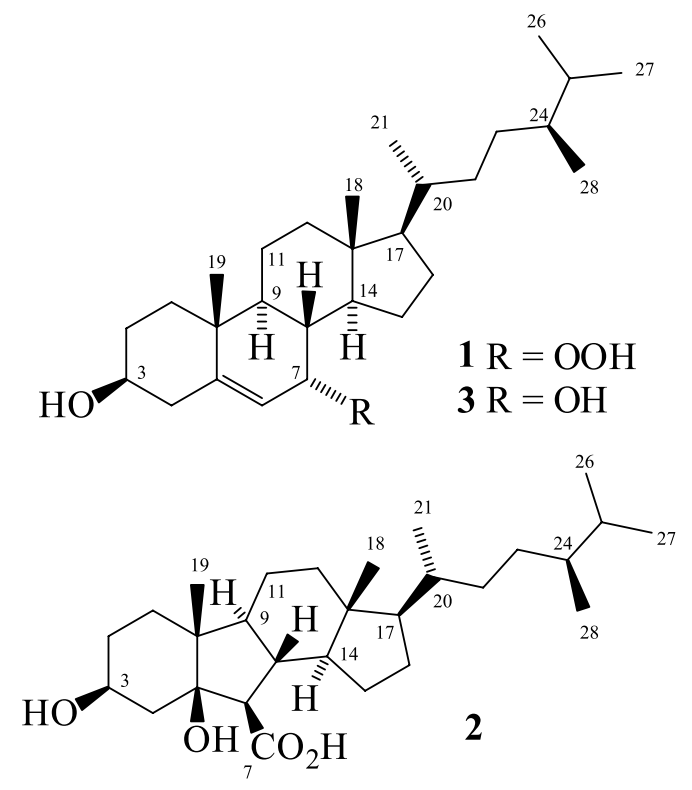

Figure 2. Chemical structures of the sterols 1-3. 
$\mathrm{C}_{28} \mathrm{H}_{48} \mathrm{O}_{3}$ deduced by HRESIMS analysis, by measurement of the protonated molecular ion peak $[\mathrm{M}+\mathrm{H}]^{+}$at $m / z 433.3597$ (calcd. 433.3676), and by ${ }^{13} \mathrm{C}$ NMR-CPD (composite pulse decoupling) analysis. Comparing the ${ }^{13} \mathrm{C}$ NMR data of $\mathbf{1}$ with those of $7 \alpha$-hydroxycampesterol (3) ${ }^{19}$ also isolated in this work (Table 1), a good match was observed, but with a significant difference for the corresponding chemical shift of the C-7 oxymethine carbon, $\delta_{\mathrm{C}} 78.6$ for $\mathbf{1}$ instead of 65.8 for $3\left(\Delta \delta_{\mathrm{C}} 12.8 \mathrm{ppm}\right)$. This is in agreement with a carbon bearing a hydroperoxy moiety $(-\mathrm{OOH}),{ }^{20}$ as supported by the molecular formula $\mathrm{C}_{28} \mathrm{H}_{48} \mathrm{O}_{3}$. In fact, the HSQC (heteronuclear single quantum correlation) spectrum exhibited correlations for the protons at $\delta_{\mathrm{H}} 4.15$ (br s, 1H, H-7) and $3.62(\mathrm{~m}, 1 \mathrm{H}, \mathrm{H}-3)$ with the carbons at $\delta_{\mathrm{C}} 78.6(\mathrm{C}-7)$ and $71.5(\mathrm{C}-3)$, respectively, in agreement with the chemical shifts for oxymethines bearing a peroxyl and a hydroxyl groups, respectively. ${ }^{20}$ The deshielding of H-7/C-7 $\left(\delta_{\mathrm{H}} / \delta_{\mathrm{C}} 4.15 / 78.6\right)$, when compared with H-3/C-3 $\left(\delta_{\mathrm{H}} / \delta_{\mathrm{C}} 3.62 / 71.5\right)$, is due to the $\beta$-effect of the additional oxygen of the hydroperoxyl group when compared with that of the corresponding hydroxyl group of $\mathbf{3} \cdot{ }^{19}$ According with the above data, and by analysis of the COSY (correlation spectroscopy) and HMBC (heteronuclear multiple bond correlation) spectra (Figure 3a), the structure of 1 was established. The NOESY (nuclear Overhauser effect spectroscopy) spectrum did not show any key correlations to prove the $\beta$-position for HO-3 and the $\alpha$-position for HOO-7. However, comparison of the carbon chemical shifts of $\mathbf{1}$ with those reported to $7 \alpha$-hydroperoxycholesterol (1a) and $7 \beta$-hydroperoxycholesterol (1b) ${ }^{20}$ (Figure $3 b$ ), showed a very close similarity with the 1a, particularly for the chemical shifts related to the carbocyclic chain (Figure 3c). Thus, the structure of compound $\mathbf{1}$ was defined as 7 $\alpha$-hydroperoxycampesterol.

a)
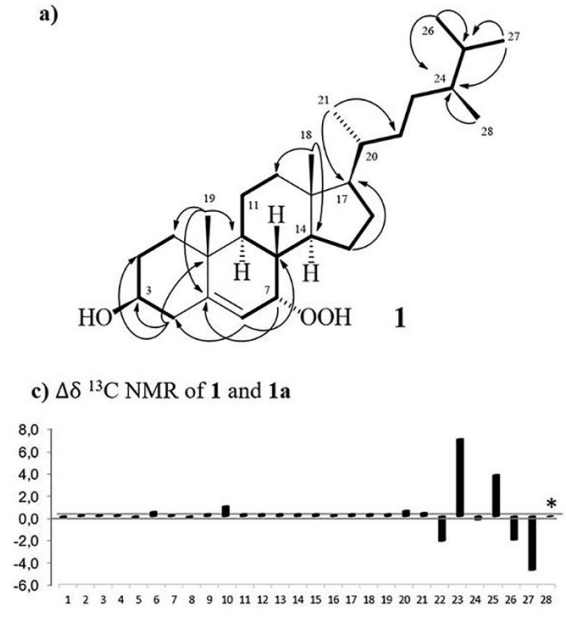

Compound 2, an amorphous white powder, had its $\mathrm{C}_{28} \mathrm{H}_{48} \mathrm{O}_{4}$ molecular formula determined by HRESIMS, based on the deprotonated molecular ion peak $[\mathrm{M}-\mathrm{H}]^{-}$at $\mathrm{m} / z$ 447.3498 (calcd. 447.3474), ${ }^{13} \mathrm{C}$ CPD and DEPT 135 NMR spectra. Its IR spectrum $(\mathrm{KBr})$ exhibited absorption bands at $3.492\left(\mathrm{v}_{\mathrm{OH}}\right)$ and $1.711\left(\mathrm{v}_{\mathrm{CO}}\right) \mathrm{cm}^{-1}$ indicating a carboxyl function. Comparison of ${ }^{1} \mathrm{H}$ and ${ }^{13} \mathrm{C}$ NMR spectra of $\mathbf{2}$ with those of $\mathbf{1}$ (Table 1), revealed that these compounds share the same ergostane backbone, but with significant differences in the chemical shifts related to the A and B rings. In the ${ }^{13} \mathrm{C}$ CPD and DEPT NMR spectra, signals corresponding to oxymethine carbons at $\delta_{\mathrm{C}} 67.3$ (C-3) and $58.7(\mathrm{C}-6)$, and of a tertiary alcohol carbon at $\delta_{\mathrm{C}} 82.9$ (C-5), in addition to a carboxylic acid at $\delta_{\mathrm{C}} 178.2$ (C-7) were observed. The unequivocal position for the two hydroxyl groups, including the carboxyl acid moiety, was supported by the HMBC spectrum. Correlations were observed for the diastereotopic methylene protons at $\delta_{\mathrm{H}} 1.64 / 1.62(\mathrm{~m}$, $2 \mathrm{H}, \mathrm{H}-2)$ and 2.13/1.68 (m, 2H, H-4) with the oxymethine carbon at $\delta_{\mathrm{C}} 67.3(\mathrm{C}-3)$, as well as the methyl signal at $\delta_{\mathrm{H}} 0.96(\mathrm{~s}, 3 \mathrm{H}, \mathrm{H}-19)$ with the non-hydrogenated carbon at $\delta_{\mathrm{C}} 82.9(\mathrm{C}-5)$ supporting the presence of two hydroxyl groups at C-3 and C-5, respectively. Likewise, correlations for the protons at $\delta_{\mathrm{H}} 2.27(\mathrm{H}-6)$ and $2.09(\mathrm{H}-8)$ with the carbon at $\delta_{\mathrm{C}} 178.2(\mathrm{C}-7)$ warrant the carboxyl group at C-6. These data, including COSY and HMBC analyses (Figure 4a) were in agreement with a rearranged five membered ring $\mathrm{B}$ of a nor-ergostane sterol. ${ }^{21}$ These kind of $\mathrm{C}_{6}-\mathrm{C}_{5}-\mathrm{C}_{6}-\mathrm{C}_{5}$ tetracyclic ergostane steroids are rare in nature. Few examples include similar sterols isolated from the sponges Stelletta hiwasaensis ${ }^{22}$ and Svenzea zeai. ${ }^{23}$ The $\beta$-positions for both hydroxyl groups at C-3 and C-5, for the carboxyl acid moiety at C-6, and the side chain at $\mathrm{C}-17$, including the cis-configuration for the fused A/B

b)
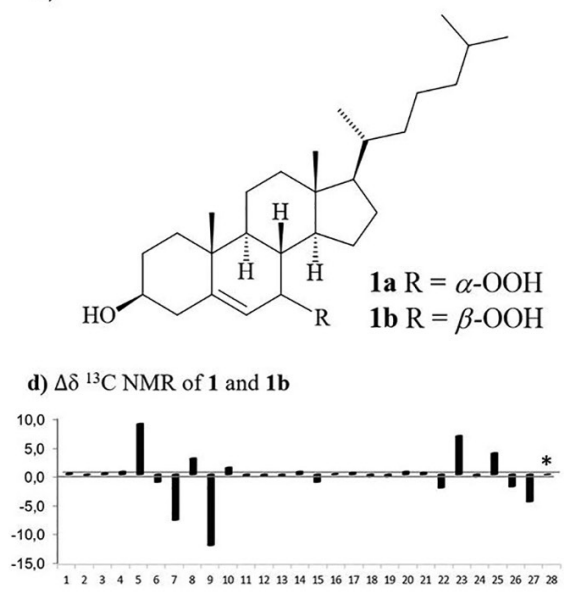

Figure 3. (a) Key ${ }^{1} \mathrm{H}^{-1} \mathrm{H}$ COSY $(\mathrm{H}-\mathrm{H})$ and $\mathrm{HMBC}(\mathrm{H} \rightarrow \mathrm{C})$ correlations for 1; (b) structures of $7 \alpha$-hydroperoxycholesterol (1a) and 7 $\beta$-hydroperoxycholesterol (1b); (c) ${ }^{13} \mathrm{C}$ NMR comparison for $\mathbf{1}$ and $\mathbf{1 a}$, and (d) $\mathbf{1}$ and $\mathbf{1 b}$. $^{20} * \mathrm{Me}-28$ does not exist in cholestane sterols. 


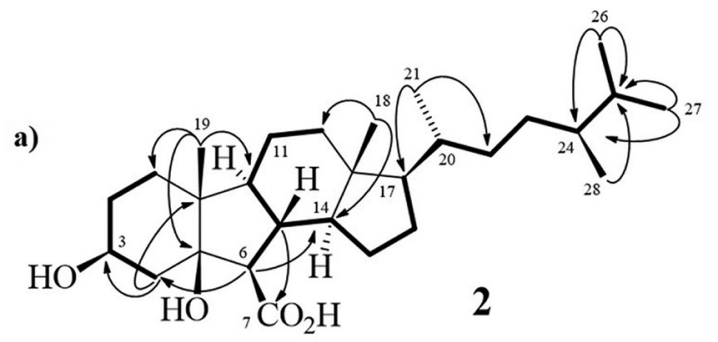

b)
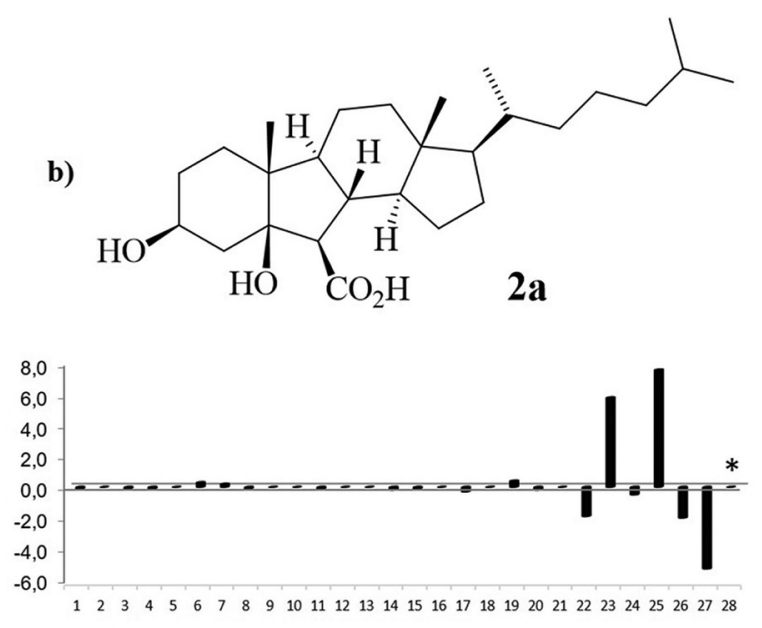

c) $\Delta \delta{ }^{13} \mathrm{C}$ NMR of $\mathbf{2}$ and $\mathbf{2 a}$

Figure 4. (a) $\mathrm{Key}{ }^{1} \mathrm{H}-{ }^{1} \mathrm{H} \operatorname{COSY}(\mathrm{H}-\mathrm{H})$ and $\mathrm{HMBC}(\mathrm{H} \rightarrow \mathrm{C})$ for compound

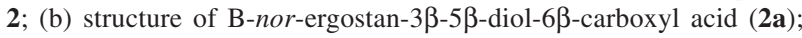
(c) ${ }^{13} \mathrm{C}$ NMR comparison between $\mathbf{2}$ and $\mathbf{2 a} .{ }^{21} * \mathrm{Me}-28$ does not exist in cholestane sterols. rings was inferred by direct comparison of the chemical shifts described to B-nor-ergostan-3 $\beta$ - $5 \beta$-diol-6 $\beta$-carboxyl acid (2a) ${ }^{24}$ which showed a good match from $\mathrm{C}-1$ through C-21 (Figure 4b). On the other hand, the observed NOE displayed for H-6 at $\delta_{\mathrm{H}} 2.27(\mathrm{~d}, J 9.7 \mathrm{~Hz})$ with $\mathrm{H}-9$ and $\mathrm{H}-14$ both at $\delta_{\mathrm{H}} 1.16(\mathrm{~m})$, was an additional support for a $\beta$-orientation of the carboxylic acid group. ${ }^{24}$ Thus, the

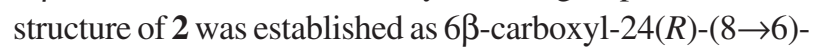
abeo-ergostan-3 $\beta, 5 \beta$-diol.

In addition to the new compounds $\mathbf{1}$ and $\mathbf{2}$, seven known sterols have also been isolated: $7 \alpha$-hydroxycampesterol (3), ${ }^{19}$ $5 \alpha, 8 \alpha$-epi-dioxycampesterol (4), ${ }^{25}$ campesterol (5), ${ }^{26} 24(R)$ ergost-7-en-3 $\beta, 5 \alpha, 6 \beta$-triol (6), ${ }^{27} 20$-hydroxyecdysone (7), ${ }^{17}$ 2-O-acetyl-20-hydroxyecdysone $(\mathbf{8})^{17}$ and 3-O-acetyl20-hydroxyecdysone $(\mathbf{9})^{17}$ (Figure S1). Additionally, GC-MS analysis of the hexane fraction (see SI), allowed the identification of the following sterols: gorgosterol ( $\mathrm{m} / \mathrm{z}$ 426), 7 $\alpha$-hydroxycampesterol $(\mathrm{m} / \mathrm{z} 416)$, campesterol $(\mathrm{m} / \mathrm{z}$ 400), crinosterol $(\mathrm{m} / \mathrm{z}, 398)$, cholest-4-en-3-one $(\mathrm{m} / \mathrm{z}$ 398), cholesta-3,5-dien-7-one $(\mathrm{m} / \mathrm{z} 396)$, cholesterol $(\mathrm{m} / \mathrm{z}, 386)$ and cholesta-5,22-dien-3-ol $(\mathrm{m} / \mathrm{z}, 384)^{10}$ (Table S2 and Figure S20).

Orostanal, an abeo-sterol isolated from a marine sponge, and its derivatives, are known to have moderated cytotoxic effects. ${ }^{28}$ The scanty literature attributes the cytotoxic activity of these class of compounds to apoptosis

Table 1. ${ }^{1} \mathrm{H}(500 \mathrm{MHz})$ and ${ }^{13} \mathrm{C}(125 \mathrm{MHz})$ NMR data for $\mathbf{1}$ and $\mathbf{2}$ in $\mathrm{CDCl}_{3}$

\begin{tabular}{|c|c|c|c|c|}
\hline & \multicolumn{2}{|c|}{1} & \multicolumn{2}{|c|}{2} \\
\hline & $\delta_{\mathrm{C}}$ & $\delta_{\mathrm{H}}($ mult, $J$ in $\mathrm{Hz})$ & $\delta_{\mathrm{C}}$ & $\delta_{\mathrm{H}}($ mult, $J$ in $\mathrm{Hz})$ \\
\hline 1 & 37.0 & $1.80(\mathrm{~m}), 1.12(\mathrm{~m})$ & 28.5 & $1.85(\mathrm{~m}), 1.28(\mathrm{~m})$ \\
\hline 2 & 31.4 & $1.86(\mathrm{~m}), 1.59(\mathrm{~m})$ & 28.2 & $1.64(\mathrm{~m}), 1.62(\mathrm{~m})$ \\
\hline 3 & 71.5 & $3.62(\mathrm{~m})$ & 67.3 & $4.06(\mathrm{~s})$ \\
\hline 4 & 42.3 & $2.42(\mathrm{~m}), 2.32(\mathrm{t}, 11.8)$ & 43.7 & $2.13(\mathrm{~m}), 1.68(\mathrm{~m})$ \\
\hline 5 & 148.8 & - & 82.9 & - \\
\hline 6 & 120.3 & $5.73(\mathrm{~d}, 3.2)$ & 58.7 & $2.27(\mathrm{~d}, 9.7)$ \\
\hline 7 & 78.6 & $4.15(\mathrm{br} \mathrm{s})$ & 178.2 & - \\
\hline 8 & 37.3 & $1.60(\mathrm{~m})$ & 42.7 & $2.09(\mathrm{~m})$ \\
\hline 9 & 43.7 & $1.30(\mathrm{~m})$ & 51.4 & $1.16(\mathrm{~m})$ \\
\hline 10 & 37.6 & - & 45.5 & - \\
\hline 11 & 21.1 & $1.50(\mathrm{~m})$ & 21.6 & $1.71(\mathrm{~m}), 1.68(\mathrm{~m})$ \\
\hline 12 & 39.2 & $2.00(\mathrm{~m}), 1.20(\mathrm{~m})$ & 39.8 & $2.03(\mathrm{~m}), 1.11(\mathrm{~m})$ \\
\hline 13 & 42.5 & - & 44.8 & - \\
\hline 14 & 49.2 & $1.42(\mathrm{~m})$ & 56.4 & $1.16(\mathrm{~m})$ \\
\hline 15 & 24.6 & $1.88(\mathrm{~m}), 1.12(\mathrm{~m})$ & 24.2 & $1.16(\mathrm{~m}), 1.51(\mathrm{~m})$ \\
\hline 16 & 28.4 & $1.90(\mathrm{~m}), 1.30(\mathrm{~m})$ & 28.4 & $1.40(\mathrm{~m}), 1.36(\mathrm{~m})$ \\
\hline 17 & 55.9 & $1.20(\mathrm{~m})$ & 55.6 & $1.11(\mathrm{~m})$ \\
\hline 18 & 11.5 & $0.66(\mathrm{~s})$ & 12.7 & $0.69(\mathrm{~s})$ \\
\hline 19 & 18.4 & $0.99(\mathrm{~s})$ & 19.3 & $0.96(\mathrm{~s})$ \\
\hline 20 & 36.3 & $1.38(\mathrm{~m})$ & 36.2 & $1.36(\mathrm{~m})$ \\
\hline 21 & 19.1 & $0.91(\mathrm{~d}, 6.6)$ & 17.7 & $0.92(\mathrm{~d}, 6.7)$ \\
\hline 22 & 33.9 & $1.32(\mathrm{~m}), 0.98(\mathrm{~m})$ & 33.9 & $1.38(\mathrm{~m}), 0.95(\mathrm{~m})$ \\
\hline 23 & 30.6 & $1.40(\mathrm{~m}), 0.99(\mathrm{~m})$ & 30.7 & $1.36(\mathrm{~m}), 0.95(\mathrm{~m})$ \\
\hline 24 & 39.2 & $1.20(\mathrm{~m})$ & 39.2 & $1.18(\mathrm{~m})$ \\
\hline 25 & 31.7 & $1.58(\mathrm{~m})$ & 31.6 & $1.55(\mathrm{~m})$ \\
\hline 26 & 20.7 & $0.86(\mathrm{~d}, 6.6)$ & 20.7 & $0.84(\mathrm{~d}, 6.7)$ \\
\hline 27 & 17.8 & $0.79(\mathrm{~d}, 6.6)$ & 17.7 & $0.78(\mathrm{~d}, 6.7)$ \\
\hline 28 & 15.6 & $0.78(\mathrm{~d}, 6.6)$ & 15.6 & $0.77(\mathrm{~d}, 6.7)$ \\
\hline
\end{tabular}


induction. ${ }^{21,28}$ The cytotoxic activity of $\mathbf{2}$ was assessed by the MTT assay against a human colorectal tumor cell line (HCT-116). Compound 2 showed inhibition concentration mean $\left(\mathrm{IC}_{50}\right)$ values of 50 and $4 \mu \mathrm{M}$ after 24 and $72 \mathrm{~h}$ treatment, respectively. Flow cytometry was performed after $24 \mathrm{~h}$ to assess the cellular concentration and viability as well (Figure 5). Compound 2 reduced cell number and increased non-viable cells at the higher concentrations. Compound $\mathbf{1}$ was not tested because it decomposed previously to the assay.

\section{A}

All events

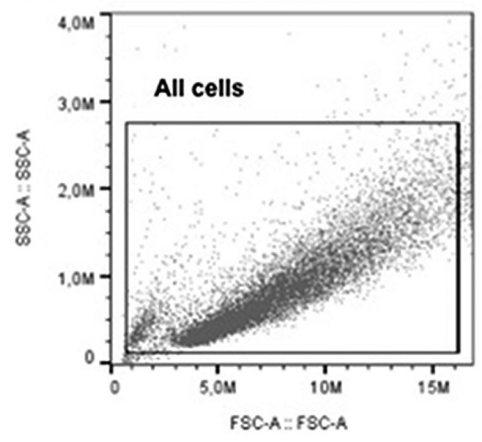

C

Singlets
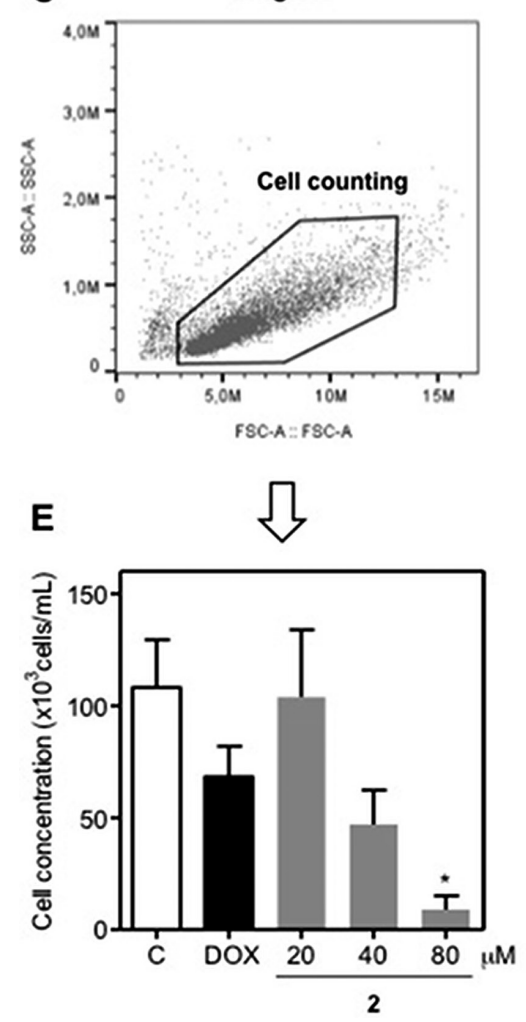

\section{Conclusions}

In this work, we described the chemical investigation of sterols from $P$. caribaeorum and $P$. variabilis. Nine sterol compounds were isolated, two of which being new. A series of cholestane and ergostane sterols were identified by GC-MS analysis. Compound $\mathbf{2}$, an uncommon $\mathrm{C}_{6}-\mathrm{C}_{5}-\mathrm{C}_{6}-\mathrm{C}_{5}$ tetracyclic abeo-ergostan sterol, showed moderate cytotoxicity against the human colorectal tumor (HCT-116) cell line.
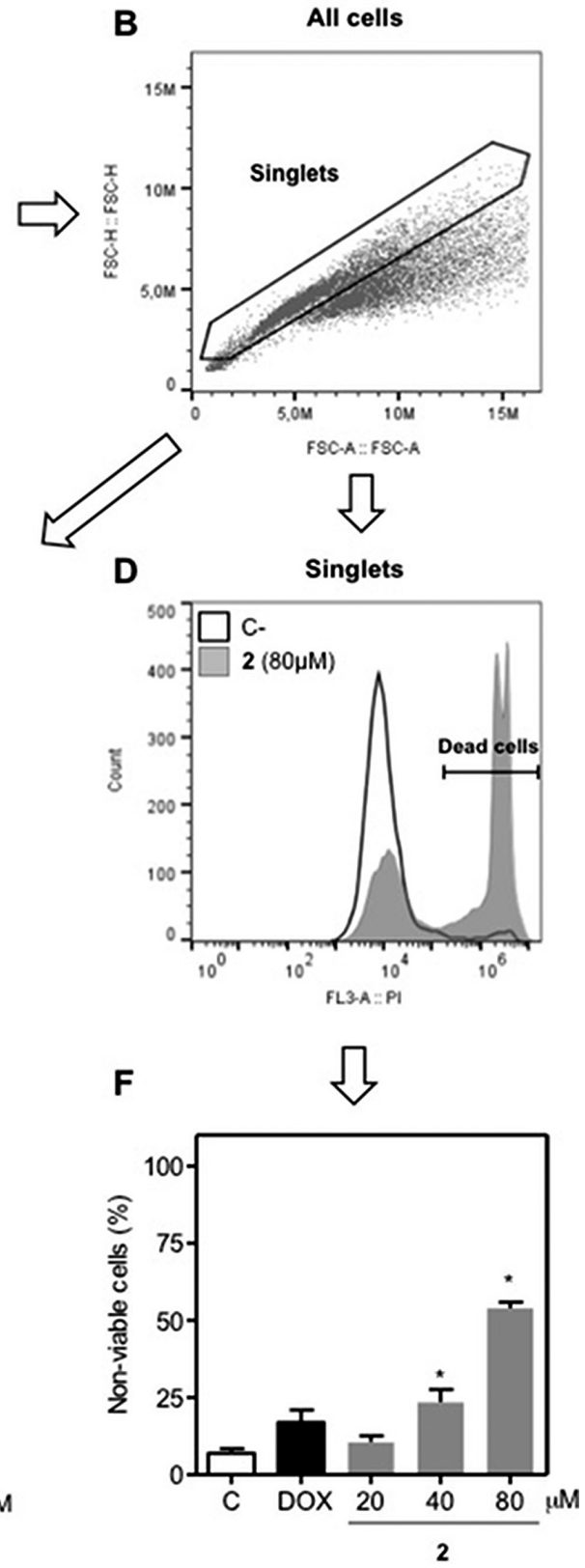

Figure 5. Treatment of cancer colon cells HCT-116 with 2 decreases cell counting and causes cell death. (A) to (D) depict gating strategies to analyze cell number (C) and dead cells stained with propidium iodide (D) among the single cells of each sample. (E) and (F) depict cell counting and percentage of dead cells, respectively. HCT-116 cells treated with DMSO at $0.4 \%(C)$, doxorubicin at $3.5 \mu \mathrm{M}(\mathrm{DOX})$ or $6 \beta$-carboxyl-24( $R$ )- $(8 \rightarrow 6)$-abeo-ergostan-3 $\beta, 5 \beta$-diol (2) at 20, 40 or $80 \mu \mathrm{M}$ during $24 \mathrm{~h}$. Ten thousand events were acquired in the singlets gate region from each sample. Data obtained from 6 experiments performed in triplicates by flow cytometric analysis. ${ }^{*} p<0.05$ compared to negative control by ANOVA followed by Dunnet's test. 


\section{Supplementary Information}

Experimental details of the isolation of the known compounds and supplementary information (Figures S1-S20 and Tables S1-S2) are available free of charge at http://jbcs.sbq.org.br as a PDF file.

\section{Acknowledgments}

The authors thank the Governmental Brazilian Agencies CNPq, FUNCAP and CAPES for financial support and fellowships.

\section{References}

1. Irei, Y.; Nozawa, Y.; Reime, J. D.; Zool. Stud. 2011, 50, 426.

2. Reimer, J.; Palythoa lamouroux, 1816, 2014. Available at World Register of Marine Species at http://www.marinespecies.org/ aphia.php?p=taxdetails\&id=205785, accessed in December 2016.

3. Hibino, Y.; Todd, P. A.; Yang, S.; Benayahu, Y.; Reimer, J. D.; Hydrobiologia 2013, 733, 31.

4. Almeida, J. G. L.; Maia, A. I. V.; Wilke, D. V.; Silveira, E. R.; Braz-Filho, R.; La Clair, J. J.; Costa-Lotufo, L. V.; Pessoa, O. D. L.; Mar. Drugs 2012, 10, 2846.

5. Imbs, A. B.; Biochem. Syst. Ecol. 2014, 54, 213; Carballeira, N. M.; Reyes, M.; J. Nat. Prod. 1995, 58, 1689; Miralles, J.; Diop, M.; Ferrel.; Kornprobst, J. M.; Comp. Biochem. Physiol. 1989, 94B, 91.

6. Hirata, Y.; Uemura, D.; Ueda, K.; Takano, S.; Pure Appl. Chem. 1979, 51, 1875; Ueda, K.; Takano, S.; Uemura, D.; Hirata, Y.; Tetrahedron Lett. 1978b, 49, 4909; Ito, S.; Hirata, Y.; Tetrahedron Lett. 1977, 28, 2429.

7. Riobó, P.; Franco, J. M.; Toxicon 2011, 57, 368.

8. Lazcano-Pérez, F.; Vivas, O.; Román-González, S. A.; Rodríguez-Bustamante, E.; Castro, H.; Arenas, I.; García, D. E.; Sánchez-Puig, N.; Arreguín-Espinosa, R.; Toxicon 2014, 82, 112; Pettit, G.; Fujii, O.; Hasler, J. A.; Schmidt, J. A. M.; Michel, C.; J. Nat. Prod. 1982, 45, 263; Pettit, G.; Fujii, O.; Hasler, J. A.; Schmidt, J. A. M.; J. Nat. Prod. 1982, 45, 272.

9. Elbagory, A. M.; Meyer, M.; Ali, A.-H. A. M.; Ameer, F.; Parker-Nance, S.; Benito, M. T.; Doyagüez, E. G.; Jimeno, M. L.; Hussein, A. A.; Steroids 2015, 101, 110; Shigemori, H.; Sato, Y.; Kagata, T.; Kobayashi, J.; J. Nat. Prod. 1999, 62, 372; Fedorov, S. N.; Stonik, V. A.; Elyakov, G. B.; Khim. Prirodn. Soedin. 1988, 4, 603.

10. Diop, M.; Leung-Tack, D.; Braekman, J. C.; Kornprobst, J. M.; Biochem. Syst. Ecol. 1986, 14, 151; Miralles, J.; Diop, M.;
Ferre, L.; Kornprobst, J. M.; Comp. Biochem. Physiol. 1988, 8, 209; Kelecom, A.; Salé-Cava, A. M.; Comp. Biochem. Physiol. 1982, 72, 677.

11. Cariello, L.; Crescenz, S.; Zanetti, L.; Comp. Biochem. Physiol. 1978, 63B, 77.

12. Han, C.; Qi, J.; Shi, X.; Sakagami, Y.; Shibata, T.; Uchida, K.; Ojika, M.; Biosci. Biotechnol. Biochem. 2006, 70, 706.

13. Wilke, D. V.; Jimenez, P. C.; Pessoa, C.; Moraes, M. O.; Araujo, R. M.; Silva, W. M. B.; Silveira, E. R.; Pessoa, O. D. L.; BrazFilho, R.; Lopes, N. P.; Costa-Lotufo, L. V.; J. Braz. Chem. Soc. 2009, 20, 1455; Wilke, D. V.; Jimenez, P. C.; Araújo, R. M.; Silva, W. M. B.; Pessoa, O. D. L.; Silveira, E. R.; Pessoa, C. O.; Moraes, M. O.; Skwarczynski, M.; Simerska, P.; Toth, I.; Costa-Lotufo, L. V.; Bioorg. Med. Chem. 2010, 18, 7997.

14. Uemura, D.; Toya, Y.; Watanabe, I.; Hirata, Y.; Chem. Soc. Jpn. 1979, 1481.

15. Moore, R. E.; Sheuer, P. J.; Science 1971, 172, 495.

16. Reimer, J. D.; Ono, S.; Takishita, K.; Tsukahara, J.; Maruyama, T.; Zool. Sci. 2006, 23, 87.

17. Cachet, N.; Genta-Jouve, G.; Ivanisevic, J.; Chevaldonne, P.; Sinniger, F.; Culioli, G.; Pérez, T.; Thomas, O. P.; Sci. Rep. 2015, 5, 1; Calcagno, M. P.; Camps, F.; Cool, J.; Melé, E.; Eur. J. Entomol. 1995, 92, 278.

18. Mosmann, T.; J. Immunol. Methods 1983, 65, 55.

19. Kobayashi, M.; Krishna, M. M.; Haribabub, B. B.; Anjaneyulu, V.; Chem. Pharm. Bull. 1993, 41, 87.

20. Sung, P.-J.; Lin, M.-R.; Chen, J.-J.; Lin, S.-F.; Wu, Y.-C.; Hwang, T.-L.; Fang, L.-S.; Chem. Pharm. Bull. 2007, 55, 666.

21. Lin, W.-H.; Fang, J.-M.; Cheng, Y.-S.; Phytochemistry 1998, 48, 1392.

22. Miyamoto, T.; Kodama, K.; Aramaki, Y.; Higuchi, R.; Soest, R. W. M. V.; Tetrahedron Lett. 2001, 42, 6349.

23. Wei, X.; Rodriguez, A. D.; Wang, Y.; Franzblau, S. G.; Tetrahedron Lett. 2007, 48, 8851.

24. Schenast, J. C.; Witter, D. P.; Grant, E.; Boldt, G. E.; Offer, J.; Wentworth, J. P.; Angew. Chem. Int. Ed. 2009, 48, 9469.

25. Ioannoua, E.; Abdel-Razika, A. F.; Zervouc, M.; Christfidisa, D.; Alexi, X.; Vagiasa, C.; Alxis, M. N.; Roussis, V.; Steroids 2009, 74, 73 .

26. Zhang, X.; Cambrail, A.; Miesch, M.; Roussi, S.; Raul, F.; Marchioni, E.; J. Agric. Food Chem. 2006, 54, 1196.

27. Madaio, A.; Piccialli, V.; Sica, D.; J. Nat. Prod. 1989, 52, 952.

28. Cui, J.; Qi, B.; Gan, C.; Liu, Z.; Huang, H.; Lin, Q.; Zhao, D.; Huang, Y.; Mar. Drugs 2015, 13, 2488.

Submitted: August 26, 2016 Published online: December 15, 2016 